\title{
Implant-Supported Screw-Retained Vs Cemented Single Crown Fabricated By CAD / CAM Technology: A Clinical Case Report
}

\author{
Angelina Vlahova*, Viktor Hadzhigaev, ZlatinaTomova, RadaKazakova, Stefan Zlatev \\ Department of Prosthetic Dentistry, Faculty of Dental Medicine, Medical University, Plovdiv, Bulgaria \\ *Corresponding author: Assoc. Prof. Angelina Vlahova, Department of Prosthetic Dentistry, Faculty of Dental Medicine, Medical University- \\ Plovdiv, Bulgaria, Tel: +359888773670/+358895428170; E-mail: a_vlahova@yahoo.com
}

\begin{abstract}
:
CAD/CAM technologies in Dental Implantology present opportunities for preliminary implant planning, surgical template design, guided surgery and fabrication of immediate and permanent implant-supported restorations. The aim of this publication is to compare two types of implant-supported single crowns-screw-retained and cemented, illustrated with a clinical case. Advantages and disadvantages of the both types of restorations are described. The choice between screw-retained and cemented implant-supported restoration is individual and depends on each clinical case.
\end{abstract}

\section{Introduction}

Nowadays CAD/CAM technologies in Dental Implantology present opportunities for preliminary implant planning and surgical template design $n^{[1,2]}$, guided surgery ${ }^{[3]}$ and fabrication of immediate and permanent implant-supported restorations ${ }^{[4]}$.

Implant-supported single crown restorationis considered as a simple and easy clinical case ${ }^{[5]}$. There are two main modalities-screw-retained and cemented modifications ${ }^{[6,7]}$. When comparing types, survival and complication rates as well as bone and soft-tissue levels, they are similar ${ }^{[8]}$. The CAD/CAM ceramics based on zirconium dioxide offers esthetic advantages for the two selections ${ }^{[9,10]}$. Zirconia abutments with bonded titanium bases provide esthetic alternatives to titanium abutments for both choices ${ }^{[11]}$. Bone- and soft-tissue responses are equivalent, but residual cement of cement-retained restorations is associated with significant soft and hard-tissue complications ${ }^{[12,13]}$. Screw-related complications are the main risk for the screw-retained modification ${ }^{[14]}$.

CAD/CAM design and fabrication have some peculiarities and need additional accessorie ${ }^{[15]}$. Scan body or scan flag is needed for the scanning process-intra oral or laboratory (on a working cast with implant analogue). Factory made titanium base has to be extra orally cemented on the final restoration-individual abutment or screw-retained crown.

The aim of this publication is to compare two types of implant-supported single crown-screw-retained and cemented, illustrated with a clinical case.

\section{Materials and methods}

A patient with a single implant Osseo integrated in the area of the first lower first molar came in the CAD/CAM Center in FDM-Plovdiv. The implant type was Alfa Bio Tec, SPI modification, with $10 \mathrm{~mm}$ length and 3,75 mm diameter. An implant-supported single crown made by CAD/CAM technology of ceramics based on zirconium dioxide was chosen as a type of restoration.

Preliminary intra oral scanning with TRIOS Intra oral Scanner, 3 Shape was performed after removal of the tissue forming screw (the emergence profile) and with a scan body [Figure 1]. The restoration was designed with the help of the computer software 3 Shape Dental System 2017 (Implant Studio application). First option was individual abutment with a crown on it [Figure 2] and the second - monolithic screw-retained single crown [Figure 3].

After finalizing the design all the restorations were milled of non-sintered $\mathrm{ZrO}_{2}$ ceramics, removed, cleaned and immersed in coloring liquid for $30 \mathrm{sec}$. Pre-Dry and Sintering Thermal Cycles in the ceramic furnace were performed, followed by slow cooling, final staining and glazing of the crowns. Factory made titanium base Alfa Bio Tec Ti-Base was necessary in order to fix the restorations on the implant.

\section{Received Date: September 13, 2017 \\ Accepted Date: March 19, 2018 \\ Published Date: March 23, 2018}

Citation: Vlahova, A., et al. Implant-Supported Screw-Retained Vs Cemented Single Crown Fabricated By CAD / CAM Technology: A Clinical Case Report. (2018) J Dent Oral Care 4(1): $5-7$.

Copyright: (C) 2018 Vlahova, A. This is an Open access article distributed under the terms of Creative Commons Attribution 4.0 International License. 


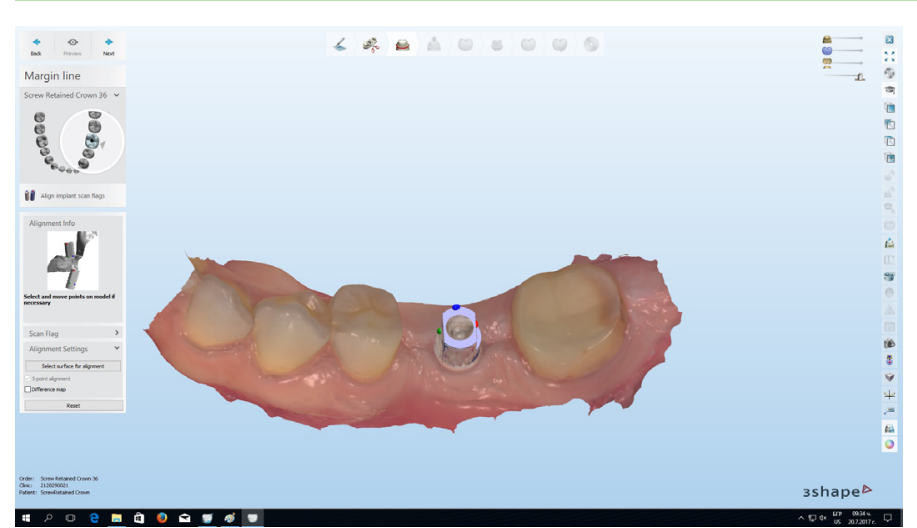

Figure 1: Scan body on the implant visualized in 3Shape Dental System 2017 Software.

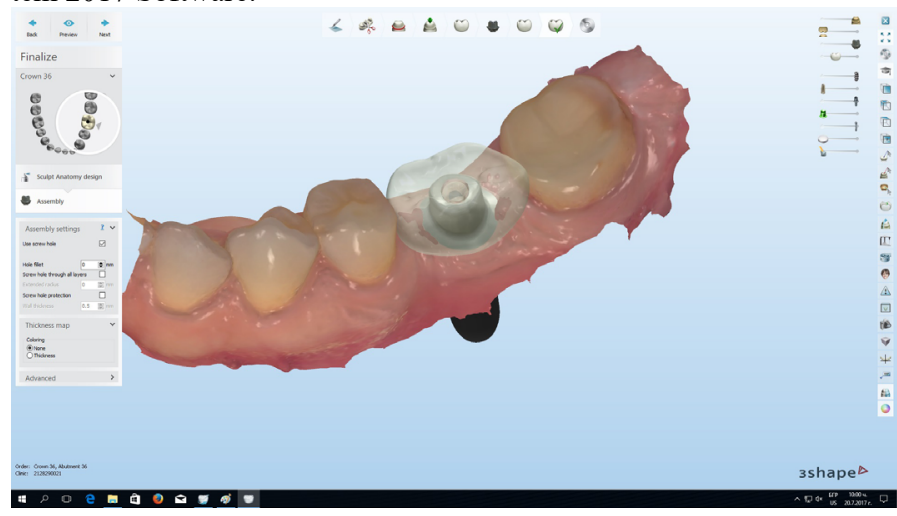

Figure 2: Finalized design of the individual abutment and the cement-retained crown on it.

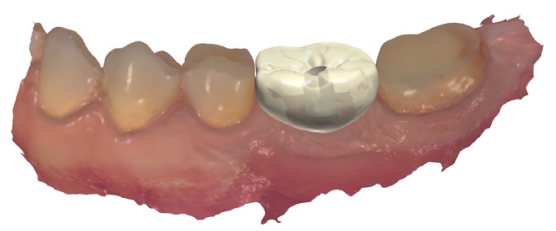

Figure 3: Preview of the final design of the screw-retained single crown.

\section{Results and discussion}

After all the restorations were finalized a try-in procedure was made in the patient mouth. First, the cemented modification-the individual abutment[Figure 4] with a crown on it, and second, the monolithic variant. After a precise inspection (in the mouth and extra orally) and a discussion the clinical case was finalized with the screw-retained single crown[Figure 5]. Extra oral cementation of the Ti-Base with composite cement was made and the excess of the residual cement was cleaned. A dynamometric key was used to achieve the desired torque. The screw-access opening was covered with light-cured composite fillings material.

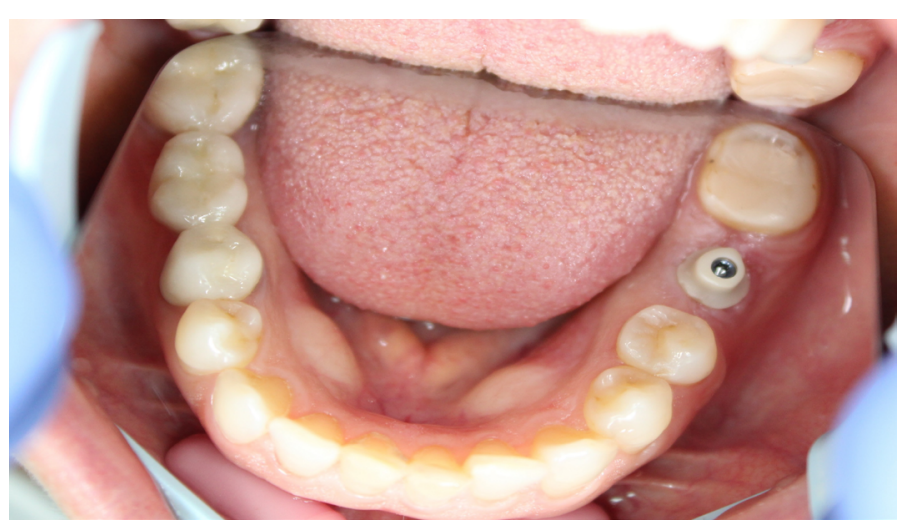

Figure 4: The individual abutment try-in procedure in the patient mouth.

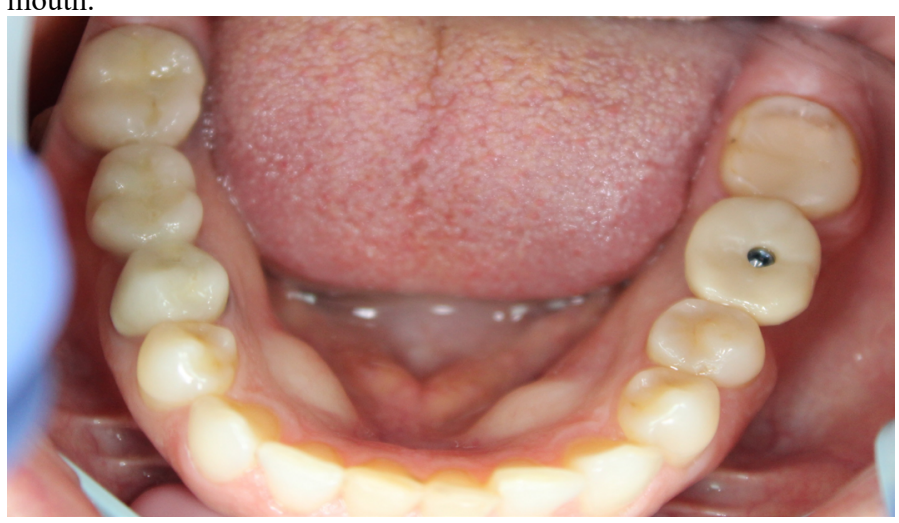

Figure 5: The final screw-retained single crown fixed on the implant interface.

The choice between screw-retained and cemented restorations is controversial ${ }^{[6]}$. Both types of single crowns have their advantages and disadvantages ${ }^{[16]}$. The comparison between the two variants shows similar survival and complication rates, bone-and soft tissues levels are close and the zirconium ceramic provides excellent esthetics ${ }^{[8]}$. Extraoral cementation with precise cleaning of the cement excess of the screw-retained restorations is their biggest advantage because this eliminates the risk of soft tissues injury and periimplantitis ${ }^{[17]}$. Another advantage is that there is a single margin ${ }^{[8]}$ between the implant interface and the restoration, which reduces the risk of gap, infection, inflammation and lack of cementation. In the case of cement-retained modification the margins are two-between the implant and the abutment and between the abutment and the crown. When TiBase is used an additional margin can be located-between the base and the restoration on the top of it. The potential weakness of ceramic discontinuity of screw-access openings can be lessened by the incorporation of stronger ceramic materials such as zirconium dioxide ${ }^{[18]}$ or lithium disilicate ceramics ${ }^{[15,19]}$ and the screw compromise is the most often possible complication (unscrewing, screw fracture, etc. $)^{[14]}$. The main remaining indication for cement-retained restorations is to compensate for angled implants, especially if they are two or more and have to be restored with crowns in block or with a bridge restoration ${ }^{[20]}$. Specific indication for this type of restorations is the clinical situation when the distance between the top of the alveolar bone and the occlusal plane in the implant area is less than $9 \mathrm{~mm}^{[18]}$. Also the cemented crowns are with higher survival rates for patients with bruxism $^{[21]}$. 


\section{Conclusion}

In conclusion, the choice between screw-retained and cemented implant-supported single crown is individual and depends on the clinical case. Modern CAD/CAM technologies present an opportunity for optimization of both options leading to an appropriate clinical solution.

Acknowledgements: This publication is partially funded by a grant of Medical University - Plovdiv, Bulgaria (University Project№ 03 / 2017). The clinical case was made in the CAD/ CAM Center in the Department of Prosthetic Dentistry, Faculty of Dental Medicine, and Medical University - Plovdiv, Bulgaria.

\section{Conflict of Interest: No conflict of interest.}

\section{References}

1. Kazakova,Pada., Vlahova,Angelina., Kisov,Hristo.CAD/CAMрево люциятавстоматологичнатапрофесия. (2014) СДК и НУC, vol. 13, бp. 2, c. 39-42 [Bulgarian]

Pubmed |Crossref |Others

2. Matta, R.E., Bergauer, B., Adler, W., et.al. The impact of the fabrication method on the three-dimensional accuracy of an implant surgery template. (2017) J Craniomaxillofac Surg. 45(6): 804-808.

Pubmed | Crossref | Others

3. Lanis, A., Álvarez Del Canto, O. The combination of digital surface scanners and cone beam computed tomography technology for guided implant surgery using 3Shape implant studio software: a case history report. (2015) Int J Prosthodont 28(2):169-78.

Pubmed |Crossref $\mid$ Others

4. Arcuri, L., Lorenzi, C., Cecchetti, F., et al. Full digital workflow for implant-prosthetic rehabilitations: a case report. (2016) Oral Implantol (Rome) 238(4): 114-121.

Pubmed | Crossref | Others

5. Vlahova A, Kazakova R, Bozhkova T, Hadzhigaev V, Zlatev St, KissovChr, Todorov G. First steps with CAD/CAM: a single crown design by 3Shape Dental System. Folia Medica 2015; 57; Suppl. 1; p. 50-51.

Pubmed |Crossref |Others

6. Nissan, J., Narobai, D., Gross, O., et al. Long-term outcome of cemented versus screw-retained implant-supported partial restorations. (2011) Int J Oral Maxillofac Implants 26(5): 1102-7.

Pubmed | Crossref | Others

7. Nissan, J., Snir, D., Rosner, O., et al. Reliability of retrievable cemented implant-supported prostheses. (2016)J Prosthet Dent 115(5): 587-91.

Pubmed | Crossref | Others

8. Priest, G. A Current Perspective on Screw-Retained Single-Implant Restorations: A Review of Pertinent Literature. (2017) J Esthet Restor Dent 29(3): 161-171.

Pubmed |Crossref|Others

9. Alfarsi, M.A., Okutan, H.M., Bickel, M. CAD/CAM to fabricate ceramic implant abutments and crowns: a preliminary in vitro study. (2009) Aust Dent J 54(1): 12-6.

Pubmed | Crossref | Others

10. Nilsson, A., Johansson, L.Å., Lindh, C., Ekfeldt, A. One-piece internal zirconia abutments for single-tooth restorations on narrow and regular diameter implants: A 5-year prospective follow-up study. (2017) Clin Implant Dent Relat Res 19(5): 916-925.

Pubmed | Crossref | Others

11. Ekfeldt, A., Fürst, B., Carlsson, G.E.,et al. abutments for single-tooth implant restorations: a 10- to 11-year follow-up study. (2016) Clin Oral Implants 28(10): :1303-1308 .

Pubmed | Crossref| Others
12. Vlahova, A., V. Hadzhigaev, R. Kazakova, S. Alexandrov, D. Shopova. Prosthetic complications in implant treatment: A clinical case. Oral Presentation. $18^{\text {th }}$ Congress of BASS, Skopje, Macedonia, 25 - 28. 04. 2013. Abstract Book, p Pubmed | Crossref $\mid$ Others

13. Amri , A. 1., Al-Rasheed, A.S., et al. Comparison of Clinical, Radiographic, and Immunologic Inflammatory Parameters Around Dental Implants with Cement-Retained and Screw-Retained Restorations: A 5-Year Prospective Cohort Study in Men. (2017) Int J Prosthodont 30(4) : 384-389.

Pubmed | Crossref| Others

14. Kourtis, S., Damanaki, M., Kaitatzidou, S. et al. Loosening of the fixing screw in single implant crowns: predisposing factors, prevention and treatment options. . ( 2017 ) J EsthetRestor Dent 29(4) : 233-246. Pubmed | Crossref | Others

15. Joda, T., Ferrari, M., Brägger, U. Monolithic implant-supported lithium disilicate (LS2) crowns in a complete digital workflow: A prospective clinical trial with a 2-year follow-up. (2017) Clin Implant Dent Relat Res 19(3): 505-511.

Pubmed | Crossref| Others

16. Clelland, N.L., Yilmaz, B., Seidt, J.D. Three-dimensional image correlation analyses for strains generated by cement and screw-retained implant prostheses. (2013) Clin Implant Dent Relat Res15(2) : 271-82. Pubmed | Crossref| Others

17. Al Amri MD, Al-Johany SS, Al-Qarni MN, Al-Bakri AS, Al-Maflehi NS, Abualsaud HS. Influence of space size of abutment screw access channel on the amount of extruded excess cement and marginal accuracy of cement-retained single implant restorations. (2017) J Prosthet Dent 119(2): 263-269.

Pubmed |Crossref| Others

18. Obermeier, M., Ristowm, O., Erdelt, K. et al. Mechanical performance of cement-and screw-retained all-ceramic single crowns on dentalimplants. (2018) Clin Oral Investig 22(2) : 981-991.

Pubmed | Crossref|Others

19. Mobilio, N., Catapano, S. The use of monolithic lithium disilicate for posterior screw-retained implant crowns. (2017) J Prosthet Dent 118(6): 703-705.

Pubmed | Crossref $\mid$ Others

20. Greer, A.C., Hoyle, P.J., Vere, J.W., et al. Mechanical Complications Associatedwith Angled Screw Channel Restorations. (2017) Int J Prosthodont 30(3) : 258-259.

Pubmed | Crossref | Others

21. Chrcanovic, B.R., Kisch, J., Albrektsson, T.et al. Bruxism and dentalimplant treatment complications: a retrospective comparative study of 98 bruxerpatients and a matched group.( 2017) Clin Oral Implants Res. 28(7): e1-e9.

Pubmed | Crossref | Others

Submit your manuscript to Ommega Publishers and we will help you at every step:

- We accept pre-submission inquiries

- Our selector tool helps you to find the most relevant journal

- We provide round the clock customer support

- Convenient online submission

- Thorough peer review

- Inclusion in all major indexing services

- Maximum visibility for your research

Submit your manuscript at

OMMEgA Publishers

https://www.ommegaonline.org/submit-manuscript 